\title{
Characteristics of immunosuppressive macrophages induced in spleen cells by Mycobacterium avium complex infections in mice
}

\author{
HaRuaki Tomioka, ${ }^{1 *}$ Hajime Saito $^{1}$ and Yoshitaka Yamada ${ }^{1,2}$ \\ Department of Microbiology and Immunology ${ }^{1}$, and Department of Dermatology ${ }^{2}$, Shimane Medical University, \\ Izumo, Shimane 693, Japan
}

(Received 30 October 1989; revised 11 January 1990; accepted 15 January 1990)

\begin{abstract}
The profile of generation and characteristics of splenic macrophages (MФs) which suppress the concanavalin $A$ (Con A) mitogenic response of splenic T cells (designated as 'immunosuppressive MФs') in host CBA/JN mice during the course of Mycobacterium avium complex (MAC) infection were investigated. In MAC-infected mice, reductions in some cellular functions of host splenic $\mathbf{T}$ cells, such as the Con $\mathbf{A}$ mitogenic response and mixed leucocyte reaction, were seen around 2 weeks after challenge of organisms, and this was accompanied by appearance of immunosuppressive $\mathbf{M \Phi s}$ in spleen cells. In this case, increase in immunosuppressive $M \Phi$ activity was seen in terms of both activity per spleen and activity per individual МФ. In this phase of the infection, MACinduced splenic MФs showed a markedly increased ability to produce reactive oxygen radicals in response to phorbol myristate acetate. Thus, the expression of suppressor activity of MAC-induced MФs seems to be closely linked to their activated state. A large proportion of the immunosuppressive MФs exhibited suppressor activity dependent on prostaglandins and membrane functions related to microfilaments. It was also found that the generation of IL-2-reactive T cell populations in response to Con A was markedly inhibited by MAC-induced splenic MФs, whereas they caused no significant reduction in the IL-2-producing ability of normal spleen cells.
\end{abstract}

\section{Introduction}

Mycobacterim avium complex (MAC) is one of the most prevalent pathogens in acquired immunodeficiency syndrome (AIDS) (Young et al., 1986). MAC is highly resistant to the majority of antituberculous and antimicrobial agents and frequently causes fatal infections (Wolinsky, 1979). It persists for long periods without producing the severe foci in target organs which are noted in cases of tuberculosis (Woods \& Washington, 1987). In MAC, as well as in other mycobacterial infections, depression of delayed-type hypersensitivity, the blastogenic response of lymphocytes, and in vivo antibody response (Ellner, 1978; Wadee \& Rabson, 1981; Orme \& Collins, 1984; Watson \& Collins, 1981) have been reported. Although suppressor $\mathrm{T}$ cells and immunosuppressive macrophages (MФs) are thought to contribute to the impaired cellular immunity (Bullock $e t$

Abbreviations: Con A, concanavalin A; FBS, foetal bovine serum; HBSS, Hanks' balanced salts solution; IL-2, interleukin 2; MAC, Mycobacterium avium complex; $\mathrm{M} \Phi$, macrophage; NBT, nitroblue tetrazolium; PMA, phorbol myristate acetate; SPCs, spleen cells; dThd, thymidine. al., 1978; Turcotte \& Lemieux, 1982; Edwards et al., 1986), the precise role of the latter cells in the establishment of immunosuppression (mainly antigenspecific immune unresponsiveness to MAC) remains to be elucidated. In this study, we examined the mode of generation and some properties of immunosuppressive $M \Phi$ s during the course of MAC infection induced in mice.

\section{Methods}

Organisms. M. avium complex $31 \mathrm{~F} 093 \mathrm{SmT}$ and $\mathrm{N}-260 \mathrm{SmT}$ variants were obtained from F. Kuze, Kyoto University, Kyoto, Japan, and T. Mitsui, Sanyoso National Hospital, Yamaguchi, Japan, respectively. Before starting the experimental infection study, the organisms were transferred to mice. These strains were identified as $\boldsymbol{M}$. intracellulare using the Gen-Probe Rapid Diagnostic System for MAC. Strain N-260 was found to belong to serovar 16 by a seroagglutination test.

Mice. Male CBA/JN mice were purchased from Charles River Japan.

Medium. RPMI 1640 medium (Nissui Pharmaceutical Co.) supplemented with $25 \mathrm{~mm}$-HEPES, $2 \mathrm{mM}$-glutamine, $100 \mu \mathrm{g}$ streptomycin $\mathrm{ml}^{-1}, 100$ units penicillin $\mathrm{G} \mathrm{ml}^{-1}, 5 \times 10^{-5} \mathrm{M}$-2-mercaptoethanol and $5 \%(\mathrm{v} / \mathrm{v})$ foetal bovine serum (FBS; M. A. Bioproducts) was used for cell cultures. 
Infection. Bacteria grown for 5-8 d in Dubos Tween-albumin liquid medium were harvested by centrifugation and suspended in physiological saline. A $0.2 \mathrm{ml}$ volume of bacterial suspension containing about $5 \times 10^{7}$ to $2 \times 10^{8}$ colony-forming units (c.f.u.) was given intravenously to $\mathrm{CBA} / \mathrm{JN}$ mice. Almost $100 \%$ of the inoculum produced the smooth, transparent and irregularly shaped colonies characteristic of virulent variants, when plated on $7 \mathrm{H} 10$ agar (Kubica et al., 1963).

Mitogenic response of splenic $T$ cells. The assay system was essentially as described previously (Tomioka \& Saito, 1985). Briefly, spleen cells (SPCs) from normal and infected CBA/JN mice (2 weeks after infection, unless otherwise specified) were cultured in medium usually with or without addition of $2 \mu \mathrm{g}$ concanavalin $\mathrm{A}$ (Con A) $\mathrm{ml}^{-1}$ (MilesYeda) in triplicate wells of a flat-bottomed microtitre tray for cell culture (Corning) at $37^{\circ} \mathrm{C}$ in a $\mathrm{CO}_{2}$ incubator $\left(5 \% \mathrm{CO}_{2}\right.$ and $95 \%$ humidified air) for $72 \mathrm{~h}$. The cultures were pulsed with $0.25 \mu \mathrm{Ci}$ per well of $\left[{ }^{3} \mathrm{H}\right]$ thymidine (dThd) $\left(2 \mathrm{Ci} \mathrm{mmol}{ }^{-1} ; 74 \mathrm{GBq} \mathrm{mmol}^{-1}\right.$; New England Nuclear) for the final 6-8 h. Cells were collected on glass-fibre filters and washed with physiological saline using an automatic cell harvester (Mitsumi Kagaku Co.). Radioactivity was counted in a TriCarb liquid scintillation counter (Packard Instrument $\mathrm{Co}$.).

Assay for suppressor activity of splenic $M \Phi$ s per spleen. SPCs of normal or infected mice were cultured in $\mathbf{0 . 2} \mathrm{ml}$ medium in triplicate wells of a microtitre tray at concentrations of $5 \times 10^{5}$ to $2 \times 10^{6}$ cells per well in a $\mathrm{CO}_{2}$ incubator for $2-3 \mathrm{~h}$. The wells were then vigorously rinsed with a jet of Hanks' balanced salts solution (Nissui) (HBSS). This procedure usually gave $M \Phi$ monolayer cultures (more than $95 \%$ of the cells phagocytosed latex beads), containing about $2 \times 10^{4}$ and $5 \times 10^{4}$ cells per well from $2 \times 10^{6}$ normal and infected SPCs, respectively. The number of adherent cells on the culture well increased in a nearly linear fashion as the number of SPCs seeded was increased from $5 \times 10^{5}$ to 2 $\times 10^{6}$ cells per well. Usually $1.25 \times 10^{5}$ normal SPCs in $0.2 \mathrm{ml}$ medium containing $2 \mu \mathrm{g}$ Con $\mathrm{A} \mathrm{ml}^{-1}$ were poured on to the resultant adherent cell monolayer culture. The cells were cultured at $37^{\circ} \mathrm{C}$ for $72 \mathrm{~h}$. The culture was pulsed with $\left[{ }^{3} \mathrm{H}\right] \mathrm{dTh}$ for the final $6-8 \mathrm{~h}$ of cultivation and the radioactivity was measured.

Per-organ activity of suppressive $\mathbf{M} \Phi$ s, designated as 'suppressive $M \Phi$ units per spleen' was calculated as: suppressive $\mathbf{M} \Phi$ units per spleen $=($ number of SPCs per spleen $) \div($ number of SPCs seeded to prepare the $\mathrm{M} \Phi$ monolayer which caused $50 \%$ inhibition of Con $\mathrm{A}$ blastogenesis of target splenic $\mathrm{T}$ cells).

Per-cell suppressive activity of splenic $\boldsymbol{M \Phi}$ s. Suppressive activity of individual $M \Phi$ s against mitogenesis of splenic $\mathrm{T}$ cells was determined as follows. SPCs $\left(7 \times 10^{7}\right)$ of MAC-infected mice were cultured in $7 \mathrm{ml}$ medium in an $80 \mathrm{~mm}$ plastic culture dish (Corning) at $37^{\circ} \mathrm{C}$ for $2 \mathrm{~h}$. Nonadherent cells were removed by vigorous vibration on an S/IUL mixer at a maximum speed for $15 \mathrm{~s}$ followed by rinsing with HBSS containing $1 \%(\mathrm{v} / \mathrm{v})$ FBS (three times). Adherent cells were then harvested by gentle scraping with a rubber policeman, and added to the culture system of normal SPCs $\left(1.25 \times 10^{5}\right.$ cells per well) for Con A mitogenesis at doses of $6.25 \times 10^{3}$ to $2 \times 10^{5}$ cells per well. Per-cell suppressive activity of the test $M \Phi$ s was represented by the reciprocal of the number of MФs needed for $50 \%$ inhibition of SPC mitogenesis.

Interleukin $2(I L-2)$ assay. SPCs $\left(1.25-2.5 \times 10^{6}\right)$ were cultured in 0.2 $\mathrm{ml}$ medium in microtitre wells in the presence or absence of MACinduced splenic $\mathrm{M} \Phi$ s at $37^{\circ} \mathrm{C}$ for $24 \mathrm{~h}$. The culture supernatant was harvested and its IL-2 activity determined by measuring the proliferative response of Con A blastoid cells to IL-2 (method A), according to Hoffenbach et al. (1983), or using an IL-2-dependent cytotoxic T cell line (CTLL-2) as a target cell (method B).

In method $\mathrm{A}$, Con $\mathrm{A}$ blastoid cells were prepared by cultivation of normal SPCs for $48 \mathrm{~h}$ in medium containing $5 \mu \mathrm{g} \mathrm{Con} \mathrm{A} \mathrm{ml-1}$ and subsequent rinsing with HBSS containing $10 \mathrm{mg}$ methyl $\alpha$-D-mannoside $\mathrm{ml}^{-1}$. The resultant cells $\left(3 \times 10^{4}\right)$ were cultivated in medium containing the test SPC-culture fluid $(50 \%, \mathrm{v} / \mathrm{v})$ and $10 \mathrm{mg}$ methyl $\alpha$-Dmannoside $\mathrm{ml}^{-1}$ for $72 \mathrm{~h}$, and $\left[{ }^{3} \mathrm{H}\right] \mathrm{dTh}$ incorporation during the final 6-8 $\mathrm{h}$ incubation was measured.

In method B, CTLL- 2 cells $\left(1 \times 10^{4}\right.$ cells per well $)$ were cultivated in medium containing the test SPC-culture fluid $(50 \%, \mathrm{v} / \mathrm{v})$ and $10 \mathrm{mg}$ methyl $\alpha$-D-mannoside $\mathrm{ml}^{-1}$ for $24 \mathrm{~h}$ and $\left[{ }^{3} \mathrm{H}\right] \mathrm{dTh}$ incorporation during the final $4 \mathrm{~h}$ incubation was measured.

The IL-2 activity was expressed as $\left[{ }^{3} \mathrm{H}\right] \mathrm{dTh}$ incorporation either by Con A blastoid cells or by CTLL- 2 cells.

Generation of IL-2-reactive $T$ cell subpopulations. Normal SPCs $(1.25$ $\times 10^{5}$, or in some experiments $2 \times 10^{5}$ cells per well) were cultivated in medium containing $2 \mu \mathrm{g}$ Con A ml-1 in the presence or absence of MAC-induced splenic $\mathbf{M} \Phi$ s for $48 \mathrm{~h}$. Nonadherent cells were then harvested, transferred to new wells, thoroughly washed with HBSS containing $1 \%(\mathrm{v} / \mathrm{v})$ FBS and $20 \mathrm{mg}$ methyl $\alpha$-D-mannoside $\mathrm{ml}^{-1}$, and their proliferative response to exogenous IL-2 (about 1 unit ml $^{-1}$ ) was measured during a further $72 \mathrm{~h}$ cultivation. IL-2 at 1 unit $\mathrm{ml}^{-1}$ induced a proliferative response of CTLL- 2 cells ( $10^{4}$ cells per well) of $5 \times 10^{3}$ c.p.m.

Treatment of splenic $\boldsymbol{M} \Phi_{\text {s }}$ with indomethacin and cytochalasin B. MAC-

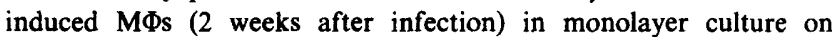
microtitre wells were treated with either indomethacin or cytochalasin B at $37^{\circ} \mathrm{C}$ for $2 \mathrm{~h}$. After washing the M $\Phi$ monolayer with HBSS, $1.25 \times$ $10^{5}$ normal SPCs were co-cultured with the indicated number of MФs so obtained for $72 \mathrm{~h}$ in the presence of $2 \mu \mathrm{g} \mathrm{Con} \mathrm{A} \mathrm{ml} l^{-1}$, and $\left[{ }^{3} \mathrm{H}\right] \mathrm{dThd}$ incorporation during the final $8 \mathrm{~h}$ of incubation was measured. In some experiments, SPCs were co-cultured with MAC-induced splenic MФs in the presence or absence of $1 \mu \mathrm{g}$ indomethacin $\mathrm{ml}^{-1}$ for $72 \mathrm{~h}$. In this case, indomethacin alone did not affect the splenic $\mathrm{T}$ cell mitogenesis in response to $2 \mu \mathrm{g}$ Con $\mathrm{A} \mathrm{ml}^{-1}$.

Superoxide anion $\left(\mathrm{O}_{2}^{-}\right)$generating ability of splenic adherent cells. SPCs $\left(1 \times 10^{6}\right)$ of normal or infected mice were cultured in $1 \mathrm{ml}$ medium in $16 \mathrm{~mm}$ culture wells containing a $14 \mathrm{~mm}$ plastic sheet (Wako Chemical Ind.) at $37^{\circ} \mathrm{C}$ for $3 \mathrm{~h}$ and washed three times with a jet of HBSS. The resulting monolayer culture on the sheet was incubated in $1 \mathrm{ml}$ medium containing $1 \mathrm{mg}$ nitroblue tetrazolium (NBT) $\mathrm{ml}^{-1}$ in the presence or absence of $100 \mathrm{ng}$ phorbol myristate acetate (PMA; Sigma) $\mathrm{ml}^{-1}$ at $37^{\circ} \mathrm{C}$ for $30 \mathrm{~min}$, then fixed with $4 \%$ (v/v) $\mathrm{HCHO}$, and the number of NBT-reducing cells counted. Cells with more than 20 blue granules were counted as positive for NBT reduction.

Chemiluminescence. Test SPCs $\left(4 \times 10^{6}\right)$ or plastic-dish-adherent cells prepared from MAC-infected SPCs $\left(2 \times 10^{5}\right)$ were suspended in 1 $\mathrm{ml} \mathrm{HBSS}$ (pH 7.4; free of phenol red) containing $10 \mathrm{mM}-\mathrm{HEPES}$ and $0 \cdot 1$ mM-luminol (Wako), then $100 \mathrm{ng}$ PMA dissolved in $10 \mu \mathrm{l}$ dimethylsulphoxide was added to the incubation mixture and photoemission was measured in a lumiphotometer, (Lumicounter ATP-237; Toyo Kagaku Ind.) at $37^{\circ} \mathrm{C}$.

\section{Results}

\section{Changes in some cellular functions of splenic $T$ cells} during the course of MAC infection

SPCs from MAC-infected mice at various phases of infection (week 1 to week 6) were measured for mitogenic response, IL-2 production, and generation of IL-2-reactive $T$ cells in response to Con A (data not shown). Mitogenesis induced by Con A $\left(2 \mu \mathrm{g} \mathrm{ml}^{-1}\right)$ was reduced most markedly around 2 weeks after infection, 


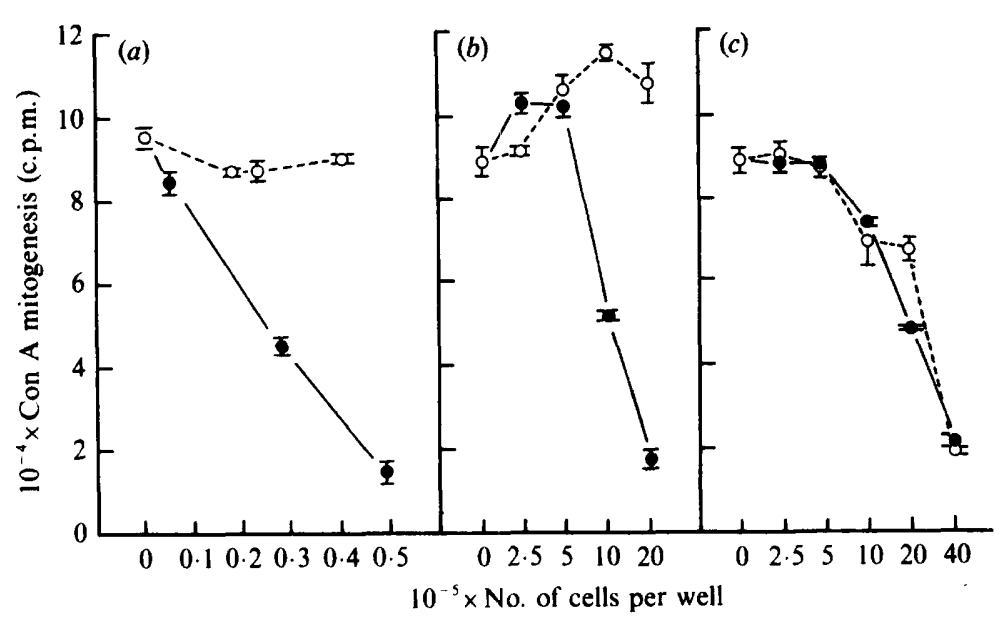

Fig. 1. Effects of plastic adherent $(a)$, Thy-1,2- $(b)$, and Sephadex G-10 nonadherent $(c)$ cell populations of normal $(O)$ and MACinfected $(O)$ SPCs on the Con A $\left(2 \mu \mathrm{g} \mathrm{ml}^{-1}\right)$ mitogenic response of splenic T cells $\left(5 \times 10^{5}\right.$ cells per microtitre well). (a) Monolayer cultures of the adherent cells were prepared by incubating test SPCs on microtitre wells at $37^{\circ} \mathrm{C}$ for $2-3 \mathrm{~h}$, followed by subsequent vigorous rinsing with HBSS. (b) Thy-1,2- cells were prepared from test SPCs $\left(2 \times 10^{7}\right.$ cells $\left.\mathrm{ml}^{-1}\right)$ by treating with anti-Thy-1,2 monoclonal antibody (1/20 dilution) (Cedarlane Laboratories) and subsequently treated with guinea-pig complement. (c) Sephadex G10 nonadherent cells were prepared by applying test SPCs $\left(4 \cdot 5 \times 10^{8}\right.$ cells) to a Sephadex G-10 column ( $20 \mathrm{ml}$ bed volume) and collecting the cells that passed through the column after $30 \mathrm{~min}$ incubation at $37^{\circ} \mathrm{C}$. Each point plotted indicates the mean \pm SEM (three incubations).

with concomitant reductions in IL-2-producing ability and generation of IL-2-reactive $T$ cells. A marked reduction in SPC mitogenesis was usually found when the SPCs were cultured at cell densities higher than $5 \times$ $10^{5}$ cells per well. In this phase of infection, the number of SPCs as well as spleen weight increased markedly. In a separate experiment, we also observed a $44 \%$ and $72 \%$ reduction in the mixed leucocyte reaction of MACinfected SPCs (2 weeks after infection) against mitomycin-C-treated BALB/c SPCs, when the responder cells were cultured at densities of $5 \times 10^{5}$ and $1 \times 10^{6}$ cells per well, respectively.

\section{Role of immunosuppressive $M \Phi$ s in reduction of Con $A$ mitogenesis of MAC-infected SPCs}

Fig. 1 shows that SPCs of MAC-infected mice (2 weeks after infection) contained two types of suppressor cells against the Con-A induced mitogenesis of normal splenic $\mathrm{T}$ cells.

Firstly, plastic-adherent cells and Thy-1,2- cells inhibited SPC mitogenesis in the same fashion (Fig. $1 a$, b). In separate experiments, more than $95 \%$ of the adherent cells were identified as $M \Phi$ on the basis of morphology and strong phagocytic ability against latex beads and sheep erythrocytes. Therefore, one component of the suppressor cell population in the MAC-infected SPCs is immunosuppressive MФs. In this case, suppressive activity was noted only for the adherent cells from
MAC-infected SPCs, and not for those from normal SPCs.

Secondly, a cell population which passed through a Sephadex G-10 column (M $\Phi$-depleted cell population) also suppressed SPC mitogenesis (Fig. 1c). In this case, $M \Phi$-depleted cells from SPCs of normal mice showed the same level of suppressive activity as those from MACinduced SPCs. Therefore, MAC infection at this phase (2 weeks after bacterial challenge) is thought mainly to elicit immunosuppressive $M \Phi$ s.

The observed suppression of splenic $T$ cell mitogenesis by co-culture with MAC-induced splenic MФs was not due to depletion of nutrients, because daily half medium changes did not overcome the suppression (data not shown). MAC-induced splenic $\mathbf{M} \Phi$ s also inhibited phytohaemagglutinin-induced mitogenesis of splenic $\mathrm{T}$ cells in the same manner as Con-A-induced mitogenesis (data not shown). Furthermore, treatment of MACinduced splenic M $\Phi$ s with anti-I-A, I-E, or I-J antibody plus complement failed to abolish the suppressor activity of the $M \Phi s$, although a partial reduction in suppressive activity was seen after anti-I-E or anti-I-J antibody treatment (statistically insignificant; $P>0 \cdot 1$ ). This suggests that the main cell populations of the suppressor MФs do not express I-A, I-E or I-J antigen.

Fig. 2 shows the suppressive effect of MAC-induced splenic MФs against Con A mitogenesis of normal or MAC-infected SPCs and splenic T cells. The MACinduced $M \Phi$ s inhibited Con A mitogenesis of normal and 
MAC-infected SPCs in the same fashion (Fig. 2a). The MAC-induced MФs inhibited the mitogenic response of splenic $T$ cells prepared from normal and from MACinfected mice in nearly the same fashion (Fig. $2 b$ ). However, it is noteworthy that splenic $\mathrm{T}$ cells were more resistant to the suppressive action of the MAC-induced $M \Phi s$, than were SPCs. This suggests that certain types of cell populations in SPCs amplify the suppressive action of the MAC-induced immunosuppressive MФs. In this experiment, MAC-infected SPCs seeded at a density of $2 \times 10^{5}$ cells per well showed similar levels of proliferation to that of normal SPCs. However, this is not entirely surprising, since in many experiments MACinduced SPCs showed a somewhat higher mitogenic

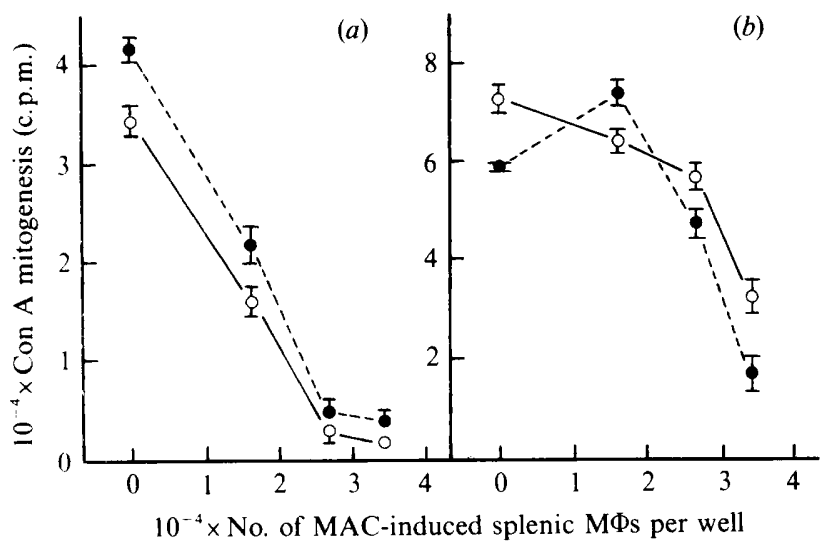

Fig. 2. Suppressive activity of MAC-induced splenic MФs against Con A mitogenesis of whole SPCs $(a)$ and splenic T cells (purified by Sephadex G-10 and nylon wool filtration $(b)$ from normal $(O)$ and MAC-infected (O) mice. Both SPCs and splenic T cells were cultured at a density of $2 \times 10^{5}$ cells per well. Each point plotted indicates the mean \pm SEM (three incubations). response than that of normal SPCs, when the SPCs were seeded at densities lower than about $2 \times 10^{5}$ cells per well. MAC-infection-induced reduction in the mitogenic response of the host SPCs was much more evident when SPCs were seeded at higher cell densities $\left(>5 \times 10^{5}\right.$ cells per well) (data not shown).

\section{Kinetics of generation of the immunosuppressive $M \Phi s$}

Table 1 shows changes in per-organ suppressive activity of the MAC-induced splenic MФs during the course of MAC infection. As described in Methods, this value represents the total activity of suppressive $M \Phi s$ in the host spleen, that is (number of suppressive $M \Phi s$ ) $\times$ (activity of individual $\mathrm{M} \Phi$ ). The value was markedly increased around 2 weeks after infection; it decreased rapidly thereafter and was almost zero by week 10 . Table 1 also shows changes in per-cell suppressive activity of the splenic $M \Phi s$ during the course of infection. This value also markedly increased around $2-4$ weeks after infection. The value could not be determined for mice 10 weeks after infection, since sufficient numbers of the adherent cells could not be obtained.

In this experiment, transient reductions in the number of organisms in the host spleen were also observed around week $2\left(4.4 \times 10^{6}, 1.0 \times 10^{6}, 3.3 \times 10^{6}\right.$ and 4.6 $\times 10^{6}$ per spleen at $1,2,4$ and 10 weeks after infection, respectively). Therefore, we expected that the splenic MФs in this phase (week 2) would have an enhanced microbicidal capacity against MAC, and thus be in the 'activated' state. In fact, splenic $M \Phi$ s induced in this phase (week 2) showed significantly enhanced spontaneous and PMA-triggered $\mathrm{O}_{2}^{-}$production. In the case of normal splenic M $\Phi$ s, the percentages of NBT-reducing

Table 1. Kinetics of generation of immunosuppressive $M \Phi$ s in SPCs of host mice during the course of MAC infection

The results are means of three determinations, \pm SEM. ND, Not determined.

\begin{tabular}{|c|c|c|c|c|}
\hline $\begin{array}{l}\text { Weeks } \\
\text { after } \\
\text { infection }\end{array}$ & $\begin{array}{c}10^{-7} \times \text { No. of SPCs } \\
\text { per mouse }\end{array}$ & $\begin{array}{c}\text { Suppressive } M \Phi \\
\text { units } \\
\text { per spleen* }\end{array}$ & $\begin{array}{l}\text { Relative per-cell } \\
\text { suppressive activity } \\
\text { of splenic } \mathrm{M} \Phi \dagger\end{array}$ & $\begin{array}{c}\text { Relative } \\
\text { chemiluminescence } \\
\text { intensity } \\
\text { of SPCs } \ddagger\end{array}$ \\
\hline 0 & $5 \cdot 2 \pm 0 \cdot 6$ & $<1.8 \pm 0.1$ & $1.00 \pm 0.04$ & $1 \cdot 0$ \\
\hline 1 & $9 \cdot 4 \pm 1 \cdot 1$ & $23 \pm 2 \cdot 7$ & $1.43 \pm 0.08$ & $1 \cdot 8 \pm 0 \cdot 1$ \\
\hline 2 & $23 \cdot 1 \pm 2 \cdot 0$ & $399 \pm 35$ & $6.97 \pm 0.46$ & $3 \cdot 8 \pm 0 \cdot 2$ \\
\hline 4 & $19 \cdot 0 \pm 1 \cdot 6$ & $211 \pm 17$ & $6.57 \pm 0.62$ & $1.4 \pm 0.1$ \\
\hline 10 & $23 \cdot 0 \pm 4 \cdot 3$ & $<0.01 \pm 0.002$ & $\mathrm{ND}$ & ND \\
\hline
\end{tabular}

* See Methods for details.

† See Methods for details. The value of each time point relative to the value at zero time (week 0 ) is indicated. The relative values shown were calculated as : (number of MФs needed for $50 \%$ inhibition of SPC mitogenesis at zero time) $\div$ (number of $\mathrm{M} \Phi$ s needed for $50 \%$ inhibition of SPC mitogenesis at the indicated time point).

$\ddagger$ The results are expressed as ratio (peak value of CL from MФs in SPCs of MAC-infected mice) $\div$ (peak value of $\mathrm{CL}$ from $M \Phi s$ in SPCs of normal mice). 
cells in the presence and absence of $100 \mathrm{ng}$ PMA ml-1 were $43 \pm 3 \%$ and $0.5 \pm 0.5 \%$ (mean $\pm \mathrm{SEM}, n=3$ ), respectively, and in the case of MAC-infected splenic $\mathbf{M} \Phi$ s ( 2 weeks after infection), the values were increased to $77 \pm 3 \%$ and $12 \pm 1 \%$, respectively. As shown in Table 1, PMA-triggered chemiluminescence was also markedly elevated around week 2. Moreover, PMAtriggered chemiluminescence (the peak value seen during 90-120 s after PMA triggering) of splenic MФs $\left(2 \times 10^{5}\right.$ cells) from MAC-infected mice was changed as follows during the early phase of infection; $304 \pm 26$ c.p.s. (week 1 ; mean \pm SEM, $n=3$ ), $976 \pm 9$ c.p.s. (week 2), and $187 \pm 7$ c.p.s. (week 4). Thus, significant activation of splenic $\mathrm{M} \Phi$ functions as determined on the basis of oxidative metabolism (Tomioka \& Saito, 1980; Saito et al., 1981) is also seen around 2 weeks after MAC infection. The functional activation in the early phase of MAC infection was also seen in peritoneal MФs (Saito et al., 1986).

\section{Mechanisms of action of MAC-induced immunosuppressive $M \Phi_{S}$}

Fig. 3(a) compares the effects of normal and MACinduced splenic $M \Phi s$ on the IL-2-producing ability of splenic $\mathrm{T}$ cells. Neither population of splenic MФs significantly inhibited IL-2 production. As shown in Table 2, IL-2 production was not changed by the MACinduced $M \Phi$ s in the SPC culture at high cell density $(1 \times$ $10^{6}$ cells per well), but it was enhanced in the SPC culture at low cell density $\left(2.5 \times 10^{5}\right.$ cells per well). Therefore, it seems that neither MAC-induced splenic MФs nor normal $\mathrm{M} \Phi$ s cause a marked reduction in the IL-2producing ability of splenic $\mathrm{T}$ cells. In separate experiments, the suppressive activity of the MAC-induced MФs was not overcome, even when a sufficient amount of exogenous IL-2 was added (data not shown). Therefore, the possibility can be excluded that the suppressor MФs inactivated or absorbed the IL- 2 molecules by binding with specific receptors.

To elucidate the effect of the MAC-induced immunosuppressive $M \Phi$ s on generation of IL-2 reactive $T$ cells in SPC culture in response to Con A signals, we carried out the following experiments.

Firstly, normal SPCs were cultured in medium containing $2 \mu \mathrm{g}$ Con A ml$l^{-1}$ in the presence or absence of either normal or MAC-induced M $\Phi$ s for $48 \mathrm{~h}$, then the nonadherent cells were harvested, transferred to new wells, and thoroughly rinsed with HBSS containing FBS and $10 \mathrm{mg}$ methyl $\alpha$-D-mannoside $\mathrm{ml}^{-1}$. Then, the resultant cells were cultured in the presence of exogenous IL-2 for a further $72 \mathrm{~h}$ and $\left[{ }^{3} \mathrm{H}\right] \mathrm{dTh}$ uptake during the final $8 \mathrm{~h}$ of cultivation was measured (Figs $3 b$ and $4 a$ ). In
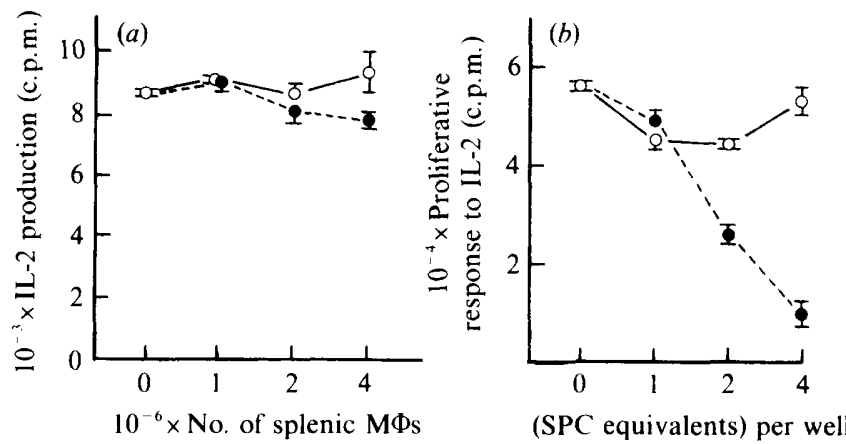

Fig. 3. Effects of normal $(O)$ and MAC-induced (O) splenic MФs (as a monolayer culture prepared by seeding the indicated number of normal or MAC-induced SPCs) on the IL-2-producing ability of splenic T cells $(a)$ and Con A-induced generation of IL-2-reactive T cells $(b)$. $(a)$ The concentration of IL- 2 in 24 h culture fluid of SPCs $\left(2 \times 10^{5}\right.$ cells per well; in medium containing $2 \mu \mathrm{g}$ Con $\mathrm{A} \mathrm{ml}^{-1}$ ) is represented by the $\left[{ }^{3} \mathrm{H}\right] \mathrm{dThd}$ incorporation of IL-2-specific CTLL-2 cells $\left(10^{4}\right.$ cells per well). (b) Normal SPCs $\left(2 \times 10^{5}\right.$ cells per well) were cultivated in medium containing $2 \mu \mathrm{g}$ Con $\mathrm{A} \mathrm{ml}^{-1}$ in the presence or absence of normal or MAC-induced splenic M $\Phi$ s for $48 \mathrm{~h}$. Nonadherent cells were then harvested, transferred to new wells, washed with HBSS containing $1 \%(\mathrm{v} / \mathrm{v})$ FBS and $10 \mathrm{mg}$ methyl $\alpha$-D-mannoside $\mathrm{ml}^{-1}$, and their proliferative response to exogenous IL-2 $\left(1 \cdot 1\right.$ units $\left.\mathrm{ml}^{-1}\right)$ measured during the final $8 \mathrm{~h}$ of a further $72 \mathrm{~h}$ cultivation. Each point plotted indicates the mean $\pm \operatorname{SEM}(n=3)$.

Table 2. Influence of $M A C$-induced splenic $M \Phi$ s on $I L-2-$ producing ability of splenic $T$ cells

The indicated number of SPCs were cultured in $\mathbf{0 . 2} \mathrm{ml}$ medium (in microtitre wells) containing $2 \mu \mathrm{g}$ Con $\mathrm{A} \mathrm{ml}^{-1}$ with or without addition of MAC-induced splenic MФs for $25 \mathrm{~h}$, and the amount of IL-2 in the culture fluid was measured on the basis of the proliferative response of Con A blastoid cells separately prepared, as described in Methods. The results are means of three determinations, \pm SEM.

\begin{tabular}{ccc}
\hline \hline $\begin{array}{c}\text { No. of } \\
\text { SPCs }\end{array}$ & $\begin{array}{c}\text { No. of MAC- } \\
\text { induced splenic MФs }\end{array}$ & $\begin{array}{c}\text { IL-2 production by } \\
\text { splenic T cells } \\
\text { (c.p.m.) }\end{array}$ \\
\hline $2.5 \times 10^{5}$ & - & $1237 \pm 50$ \\
$2.5 \times 10^{5}$ & $1.8 \times 10^{4}$ & $5189 \pm 145$ \\
$2.5 \times 10^{5}$ & $4.8 \times 10^{4}$ & $8488 \pm 734$ \\
$2.5 \times 10^{5}$ & $7.2 \times 10^{4}$ & $10753 \pm 902$ \\
$1.0 \times 10^{6}$ & - & $25625 \pm 279$ \\
$1.0 \times 10^{6}$ & $1.8 \times 10^{4}$ & $29318 \pm 4354$ \\
$1.0 \times 10^{6}$ & $4.8 \times 10^{4}$ & $36830 \pm 726$ \\
$1.0 \times 10^{6}$ & $7.2 \times 10^{4}$ & $33515 \pm 1950$ \\
- & - & $40 \pm 6$ \\
- & $1.8 \times 10^{4}$ & $36 \pm 5$ \\
- & $4.8 \times 10^{4}$ & $68 \pm 13$ \\
- & $7.2 \times 10^{4}$ & $281 \pm 178$ \\
\hline \hline
\end{tabular}

this case, the MAC-induced MФs, but not normal MФs (Fig. $3 b$ ), inhibited the generation of IL-2-reactive cell populations in the SPC culture.

Secondly, Con A blastoid cells separately prepared from normal SPCs were overlaid on to the monolayer 


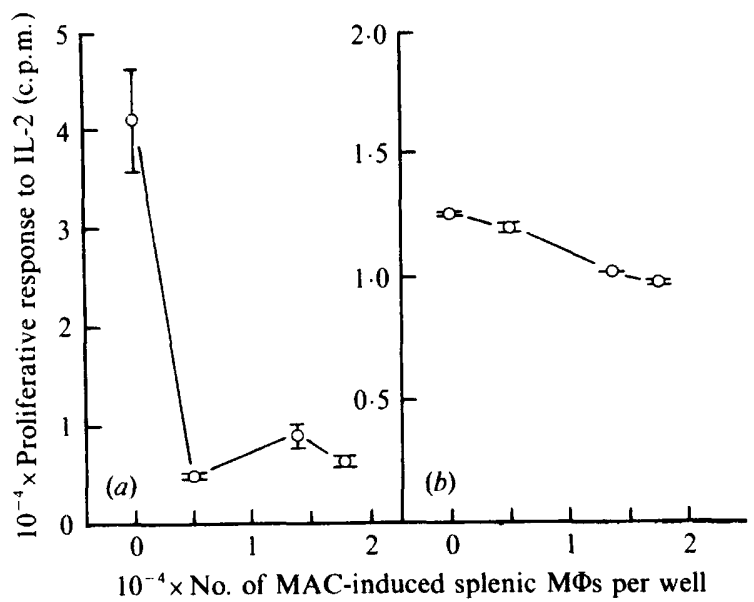

Fig. 4. Evidence for the suppression of the generation of IL-2-reactive $T$ cells without causing reduction in the IL-2-induced proliferation of the IL-2-reactive T cells by the MAC-induced splenic MФs. (a) Normal SPCs $\left(1.25 \times 10^{5}\right.$ cells per well $)$ were cultivated in medium containing $2 \mu \mathrm{g} \mathrm{Con} \mathrm{A} \mathrm{ml}{ }^{-1}$ in the presence or absence of MAC-induced splenic MФs for $\mathbf{4 8} \mathrm{h}$. Nonadherent cells were then harvested, and transferred to new wells. After washing with HBSS containing $1 \%$ (v/v) FBS and $20 \mathrm{mg}$ methyl $\alpha$-D-mannoside $\mathrm{ml}^{-1}$, their proliferative response to exogenous IL-2 $\left(0.97\right.$ units $\left.\mathrm{ml}^{-1}\right)$ during the final $8 \mathrm{~h}$ of a further $72 \mathrm{~h}$ cultivation was measured. (b) The remaining monolayer MФs in $(a)$ were examined for the effect on proliferative responses of Con $A$ blastoid cells $\left(5 \times 10^{4}\right.$ per well) in response to exogenous IL-2 $(0.97$ units $\mathrm{ml}^{-1}$ ) during the final $8 \mathrm{~h}$ of a further $72 \mathrm{~h}$ cultivation. The Con $\mathrm{A}$ blastoid cells were separately prepared from normal SPCs by activation with $5 \mu \mathrm{g}$ Con $\mathrm{A} \mathrm{ml}^{-1}$. Each point plotted indicates the mean $\pm \mathrm{SEM}$ $(n=3)$. culture of the MAC-induced $\mathrm{M} \Phi$ s which remained in the above experiment after removal of nonadherent cells, and were cultured in the presence of exogenous IL- 2 for a further $72 \mathrm{~h} .\left[{ }^{3} \mathrm{H}\right] \mathrm{dTh}$ uptake during the final $8 \mathrm{~h}$ of cultivation was measured (Fig. $4 b$ ). In this case, MACinduced $M \Phi s$ did not inhibit the proliferation of Con $\mathrm{A}$ blastoid cells in response to IL-2.

Therefore, MAC-induced splenic $\mathrm{M} \Phi$ s are thought to inhibit the activation of splenic $T$ cells to the IL-2reactive state in response to Con A signals. However, they seem not to affect the subsequent step, that is, the IL-2-induced proliferative response of IL-2-reactive T cell populations. Fluorescence-activated cell sorter (FACS) analysis using anti-mouse IL-2 receptor monoclonal antibody (clone AMT 13; Boehringer Mannheim Biochemica) showed a marked inhibition ( $49 \pm 5 \%$ in duplicate tests) of the expression of IL-2 receptors in Con-A-activated splenic $\mathrm{T}$ cells by treatment with the MAC-induced immunosuppressive MФs.

Table 3 shows the effects of treating MAC-induced MФs with indomethacin (an inhibitor of prostaglandin synthesis) and cytochalasin B (an inhibitor of microfilaments) on the expression of their suppressor action. Both agents reduced the suppressive $M \Phi$ activity in a dosedependent manner, without causing a cytotoxic effect ( $\sim 50 \mu \mathrm{g}$ indomethacin $\mathrm{ml}^{-1} ; \sim 20 \mu \mathrm{M}$-cytochalasin $\left.\mathrm{B}\right)$, indicating an important role of prostaglandins and microfilaments in the suppressor cell function of the MAC-induced MФs. However, both agents failed to

Table 3. Effects of indomethacin (indo.) and cytochalasin B (cyt B) on the activity of $M A C$-induced splenic $M \Phi_{s}$

\begin{tabular}{|c|c|c|c|c|}
\hline \multicolumn{2}{|c|}{ MAC-M $\Phi$ treatment } & \multirow{2}{*}{$\begin{array}{l}\text { No. of } \\
\text { MФs } \\
\text { added }\end{array}$} & \multirow{2}{*}{$\begin{array}{l}\text { Con A mitogenesis of SPCs } \\
\text { cocultured with MAC-MФs } \\
\text { (c.p.m.) }\end{array}$} & \multirow{2}{*}{$\begin{array}{c}\text { Residual activity } \\
\text { of suppressive MФs } \\
(\%)\end{array}$} \\
\hline Agent & Concn & & & \\
\hline - & - & - & $45581 \pm 604$ & - \\
\hline- & - & $6 \times 10^{3}$ & $21317 \pm 558$ & 100 \\
\hline Indo. & $3.2 \mu \mathrm{g} \mathrm{ml}^{-1}$ & $6 \times 10^{3}$ & $27712 \pm 3154$ & 74 \\
\hline Indo. & $12.5 \mu \mathrm{g} \mathrm{ml}^{-1}$ & $6 \times 10^{3}$ & $37591 \pm 1482$ & 33 \\
\hline Indo. & $50 \mu \mathrm{g} \mathrm{ml}^{-1}$ & $6 \times 10^{3}$ & $44541 \pm 1374$ & $0 \cdot 2$ \\
\hline - & - & $1.5 \times 10^{4}$ & $1634 \pm 830$ & 100 \\
\hline Indo. & $3 \cdot 2 \mu \mathrm{g} \mathrm{ml}^{-1}$ & $1.5 \times 10^{4}$ & $1913 \pm 625$ & 99 \\
\hline Indo. & $12.5 \mu \mathrm{g} \mathrm{ml}^{-1}$ & $1.5 \times 10^{4}$ & $2909 \pm 655$ & 97 \\
\hline Indo. & $50 \mu \mathrm{g} \mathrm{ml}^{-1}$ & $1.5 \times 10^{4}$ & $29602 \pm 2491$ & 36 \\
\hline- & - & - & $47580 \pm 1163$ & - \\
\hline - & - & $6 \times 10^{3}$ & $28035 \pm 3523$ & 100 \\
\hline Cyt B & $1.25 \mu \mathrm{M}$ & $6 \times 10^{3}$ & $19020 \pm 1895$ & 146 \\
\hline Cyt B & $5 \mu \mathrm{M}$ & $6 \times 10^{3}$ & $31189 \pm 2517$ & 84 \\
\hline Cyt B & $20 \mu \mathrm{M}$ & $6 \times 10^{3}$ & $43512 \pm 1038$ & 21 \\
\hline- & - & $1.5 \times 10^{4}$ & $581 \pm 51$ & 100 \\
\hline Cyt B & $1.25 \mu \mathrm{M}$ & $1.5 \times 10^{4}$ & $361 \pm 62$ & 100 \\
\hline Cyt B & $5 \mu \mathrm{M}$ & $1.5 \times 10^{4}$ & $1022 \pm 485$ & 99 \\
\hline Cyt B & $20 \mu \mathrm{M}$ & $1.5 \times 10^{4}$ & $28467 \pm 2771$ & 41 \\
\hline
\end{tabular}

* The results are means $\pm \operatorname{SEM}(n=3)$ 


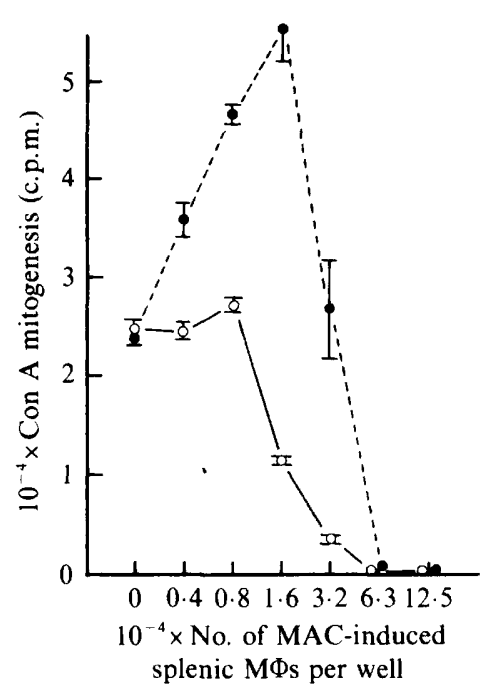

Fig. 5. Effect of indomethacin on the suppressive activity of the MACinduced MФs against Con A mitogenesis of SPCs. SPCs $\left(1.25 \times 10^{5}\right.$ cells per well) were cultivated in the presence or absence of the MACinduced splenic $\mathrm{M} \Phi \mathrm{s}$ in medium containing $2 \mu \mathrm{g}$ Con $\mathrm{A} \mathrm{ml}^{-1}$ with (O) or without $(\mathrm{O})$ the addition of $1 \mu \mathrm{g}$ indomethacin $\mathrm{ml}^{-1}$. Each point plotted indicates the mean $\pm \operatorname{SEM}(n=3)$.

overcome the suppressive activity of MAC-induced MФs when these cells were added to the SPC culture in a large dose.

Fig. 5 shows the effect of indomethacin $(1 \mu \mathrm{g} \mathrm{ml}-1)$ added during the course of Con A mitogenic cultivation of SPCs in the presence or absence of MAC-induced splenic $М Ф s$. Although this dose of indomethacin did not affect the Con A mitogenesis of splenic $T$ cells, it markedly inhibited the suppressive activity of the MACinduced $M \Phi$ s. It is noteworthy that Con A mitogenesis was considerably enhanced by the addition of indomethacin in the SPC culture with a small number of MACinduced $M \Phi s$. This suggests the possible presence of some accessory cells for Con A mitogenesis in the MACinduced splenic $M \Phi$ populations.

\section{Discussion}

In this study, we obtained evidence for the following.

Firstly, immunosuppressive MФs active against the Con A mitogenic response of splenic $\mathrm{T}$ cells were induced in the host spleen cells at a relatively early phase of MAC infection (around 2 weeks after bacterial challenge) in mice. In this case, increase in the immunosuppressive $M \Phi$ activity was seen in measurements of activity per spleen as well as activity per individual $M \Phi$. The MAC-induced splenic $M \Phi$ s had an enhanced ability to produce reactive oxygen interme- diates, one representative parameter for $\mathrm{M} \Phi$ activation (Nathan \& Root, 1977; Johnston et al., 1978; Tomioka \& Saito, 1980). Therefore, it is thought that their suppressor function is substantially linked to the 'activated state'. The suppressor activity of MAC-induced splenic MФs thereafter decreased to the normal level, despite the continuous and gradual increase in the number of the organisms in the host spleen for up to 25 weeks after bacterial challenge. A similar phenomenon was also noted in M. lepraemurium infection (Bullock et al., 1978). Although active killing of parasites by $M \Phi$ s is seen in host mice in this phase, it is possible that the present immunosuppressive $\mathbf{M} \Phi$ s transiently play some important role(s) in the establishment and progression of MAC-induced immunosuppression (particularly immune unresponsiveness to MAC) seen in the later phase of infection, which is mainly mediated by suppressor $\mathrm{T}$ cells (Watson \& Collins, 1981).

Secondly, the MAC-induced splenic MФs inhibited generation of IL-2-reactive $T$ cell populations in response to Con A without suppressing IL-2-producing ability in helper T cells. Moreover, the suppressor MФs inhibited the expression of IL-2 receptors on the Con-A-activated $T$ cell subpopulations. We interpret these findings to mean that the immunosuppressive $M \Phi$ s induced in the early phase of MAC infection, and possibly also in other mycobacterial infections, preferentially target the activation process of $\mathrm{Lyt}-1,2,3^{+} \mathrm{T}$ cells to the IL-2-reactive state in response to signals given by mitogens including Con A. This finding differs from commonly reported observations that immunosuppressive $\mathbf{M} \Phi$ s induced by microbial infections reduce the IL-2-producing activity of T cells (Hoffenbach et al., 1983; Tarleton \& Kuhn, 1984; Tossi et al., 1986). Since IL-2 production in whole SPCs decreased in the case of MAC-infected mice, some types of immunosuppressive cells other than MФs may be induced by MAC infection.

The peculiarity of immunosuppressive $\mathrm{M} \Phi$ s induced by MAC infection as compared with those induced by other mycobacterial infections could be a consequence of the course of infection of the different mycobacterial species studied. For instance, $M$. lepraemurium shows a progressive increase in bacterial load (Bullock et al., 1978), whereas MAC infection appears to be controlled at a plateau level.

The possibility that the MAC-induced splenic MФs exhibit a mitogenic inhibitory action through cytotoxic effects on the target $T$ cells, including release of some cytotoxic substances, such as arginase (Kung et al., 1977) and other toxic proteins (Chen et al., 1977), has to be considered. However, this can be excluded because the spleen cells were not killed by contact with the suppressor $\mathrm{M} \Phi$ s for $24 \mathrm{~h}$ (data not shown). Also, the MAC-induced M $\Phi$ s showed a selective inhibitory action 
on T cell functions. Although the IL-2-producing ability was not depressed, the T cell activation to the IL-2 reactive state was inhibited (Figs 3 and 4). The selective depression of IL-2-reactive $\mathrm{T}$ cell generation also excluded the possibility of participation of unlabelled dThd (Opitz et al., 1975) in the suppression of apparent $\left[{ }^{3} \mathrm{H}\right] \mathrm{dTh}$ incorporation of splenic $\mathrm{T}$ cells by MACinduced $\mathrm{M} \Phi \mathrm{s}$. It has been demonstrated that human monocytes phagocytosing $M$. tuberculosis suppress lymphocyte blastogenesis by releasing bacterial-cell-derived phospholipids which act as a suppressor cell activating factor (Wadee et al., 1983). However, the physical presence of MAC in the splenic M $\Phi$ s could not have caused the suppressor cell activity, since the number of bacilli in the $\mathrm{M} \Phi$ s was very low (four bacilli in $100 \mathrm{M} \Phi \mathrm{s}$ ).

Thirdly, the activity of the MAC-induced splenic MФs was largely mediated by prostaglandins, as already noted in other types of immunosuppressive $\mathrm{M} \Phi \mathrm{s}$ (Edwards et al., 1986; Metzger et al., 1980; Stout \& Fisher, 1983). However, indomethacin could not entirely overcome the suppressive action of the present $\mathrm{M} \Phi \mathrm{s}$, when the number of MФs added to the SPC culture was increased. This suggests that there is a prostaglandin-independent mechanism for the expression of the suppressor activity of MAC-induced splenic $\mathrm{M} \Phi s$ in addition to the prostaglandin-mediated mechanism. In fact, it is known that prostaglandins cause a relatively slight inhibition of mitogenic proliferation of $\mathrm{T}$ cells when Con $\mathrm{A}$ is used as the mitogen (Novogrodsky et al., 1979). Strong but incomplete dependency of the action of the present immunosuppressive $\mathbf{M} \Phi$ s on prostaglandins may indicate the presence of other mediators in the suppressor activity, such as $\mathrm{M} \Phi$-derived suppressor factors (SFs) (Fujiwara \& Ellner, 1986; Wadee \& Rabson, 1981). It is also possible that the MAC-induced MФs exert their suppressive function through direct cell-to-cell contact with the target cells.

Fourthly, the suppressive action of the MAC-induced splenic $M \Phi s$ was dependent on microfilament functions, because it was abolished by treatment with cytochalasin B. Microfilament inhibitors are known to inhibit some functions of $\mathrm{M} \Phi \mathrm{s}$, such as spreading, phagocytosis, and respiratory burst in response to some triggering ligands including PMA (Axline \& Reaven, 1974; Nathan \& Cohn, 1980; Tomioka \& Saito, 1987), which are dependent on membrane function of MФs. Thus, the mechanism of expression of suppressive activity of the immunosuppressive $\mathrm{M} \Phi$ s seems to be linked to certain membrane functions, such as those prerequisite for the signal transduction system or cell-to-cell interaction with target cells.

Studies are now under way using various strains of mice having the $B c g^{s}$ (MAC sensitive) and $B c g^{\mathrm{r}}$ (MAC resistant) genotypes, with special regard to the role of immunosuppressive $\mathrm{M} \Phi \mathrm{s}$ in the establishment of suppressor T-cell-mediated immune unresponsiveness.

We thank M. Ohara for reading and making helpful comments on this manuscript.

\section{References}

Axline, S. G. \& Reaven, E. P. (1974). Inhibition of phagocytosis and plasma membrane mobility of the cultivated macrophages by cytochalasin B : role of subplasmalemmal microfilaments. Journal of Cell Biology 62, 647-659.

Bullock, W. E., Carlson, E. M. \& Gershon, R. K. (1978). The evolution of immunosuppressive cell populations in experimental mycobacterial infection. Journal of Immunology 120, 1709-1716.

Chen, P. C., Gaetjens, E. \& Broome, J. D. (1977). Macromolecular inhibitory factor for lymphoid cells produced by mouse macrophages. Immunology 33, 391-398.

Edwards, C. K., III, HedegaARd, H. B., Zlotnik, A., GangadhaRAM, P. R., Johnston, R. B., JR \& PABST, M. J. (1986). Chronic infection due to Mycobacterium intracellulare in mice: association with macrophage release of prostaglandin $E_{2}$ and reversal by injection of indomethacin, muramyl dipeptide, or interferon- $\gamma$. Journal of Immunology 136, 1820-1827.

ELLNER, J. J. (1978). Suppressor adherent cells in human tuberculosis. Journal of Immunology 121, 2573-2579.

Fujiwara, H. \& Ellner, J. J. (1986). Spontaneous production of a suppressor factor by the human macrophage-like cell line U937. I. Suppression of interleukin 1, interleukin 2, and mitogen-induced blastogenesis in mouse thymocytes. Journal of Immunology 136, 181 185.

Hoffenbach, A., Lagrange, P. H. \& BaCH, M.-A. (1983). Deficit of interleukin 2 production associated with impaired $\mathrm{T}$-cell proliferative responses in Mycobacterium lepraemurium infection. Infection and Immunity 39, 109-116.

Johnston, R. B., Godzik, C. A. \& CoHN, Z. A. (1978). Increased superoxide anion production by immunologically activated and chemically elicited macrophages. Journal of Experimental Medicine 148, 115-127.

Kubica, G. P., Dye, W. E., Cohn, M. L. \& Middlebrook, G. (1963). Sputum digestion and decontamination with $N$-acetyl-L-cysteinesodium hydroxide for culture of mycobacteria. American Review of Respiratory Disease 87, 775-779

Kung, J. T., Brooks, S. B., JaKWay, J. P., LeonaRd, L. L. \& TAlMaGE, D. W. (1977). Suppression of in vitro cytotoxic response by macrophages due to arginase. Journal of Experimental Medicine 146, 665-672.

Metzger, Z., Hoffeld, J. T. \& Oppenheim, J. J. (1980). Macrophagemediated suppression. I. Evidence for participation of both hydrogen peroxide and prostaglandins in suppression of murine lymphocyte proliferation. Journal of Immunology 124, 983-988.

NATHAN, C. \& COHN, Z. (1980). Role of oxygen-dependent mechanisms in antibody-induced lysis of tumor cells by activated macrophages. Journal of Experimental Medicine 152, 198-208.

Nathan, C. F. \& Root, R. K. (1977). Hydrogen peroxide release from mouse peritoneal macrophages. Dependence on sequential activation and triggering. Journal of Experimental Medicine 146, 1648 1662.

Novogrodsky, A., Rubin, A. L. \& Stenzel, K. H. (1979). Selective suppression by adherent cells, prostaglandin, and cyclic AMP analogues of blastogenesis induced by different mitogens. Journal of Immunology 122, 1-7.

Opitz, H. G., Niethammer, D., Lemke, H., Flad, H. D. \& Hugeto, K. (1975). Inhibition of ${ }^{3} \mathrm{H}$-thymidine incorporation of lymphocytes by a soluble factor from macrophages. Cellular Immunology 16, 379388 . 
ORME, I. M. \& Collins, F. M. (1984). Immune response to atypical mycobacteria: immunocompetence of heavily infected mice measured in vivo fails to substantiate immunosuppression data obtained in vitro. Infection and Immunity 43, 32-37.

SaIto, H., Tomioka, H. \& Watanabe, T. (1981). $\mathrm{H}_{2} \mathrm{O}_{2}$-releasing function of macrophages activated with various mycobacteria based on wheat germ agglutinin and phorbol myristate acetate triggering. Journal of the Reticuloendothelial Society 29, 193-204.

SaIto, H., Tomioka, H., Yamada, Y. \& JidoI, J. (1986). Oxidative and phagocytic functions of macrophages during infections induced in mice by Mycobacterium intracellulare and Listeria monocytogenes. Journal of General Microbiology 132, 1117-1125.

Stout, R. D. \& Fisher, M. (1983). Suppression of lymphocyte proliferative responses: characterization of the suppressor and kinetics of suppression. Journal of Immunology 130, 1573-1579.

TARLETON, R. L. \& KUHN, R. E. (1984). Restoration of in vitro immune responses of spleen cells from mice infected with Trypanosoma cruzi by supernatants containing interleukin 2. Journal of Immunology 133, 1570-1575.

TOMIOKA, H. \& SAITO, H. (1980). Hydrogen peroxide releasing function of chemically elicited and immunologically activated macrophages: differential response to wheat germ lectin and concanavalin A Infection and Immunity 29, 469-476.

TоміOKA, H. \& SAITo, H. (1985). Dual effects of Ok-432 on mitogenic response of splenocytes to concanavalin A. Microbiology and Immunology 29, 349-358.

TomiokA, H. \& SAITo, H. (1987). Comparison of wheat germ agglutinin- and phorbol myristate acetate-mediated triggering for macrophage $\mathrm{H}_{2} \mathrm{O}_{2}$ release: susceptibilities to various macrophage inhibitors. Microbiology and Immunology 31, 211-221.

Tossi, Z., Kleinhenz, M. E. \& Ellner, J. J. (1986). Defective interleukin 2 production and responsiveness in human pulmonary tuberculosis. Journal of Experimental Medicine 163, 1162-1172.

TURCOTTE, R. \& LemieuX, S. (1982). Mechanisms of action of Mycobacterium bovis BCG-induced suppressor cells in mitogeninduced blastogenesis. Infection and Immunity 36, 263-270.

WadeE, A. A. \& Rabson, A. R. (1981). Production of a suppressor factor by adherent cells from Mycobacterium tuberculosis infected guinea pigs. Clinical and Experimental Immunology 45, 427-432.

WadeE, A. A., Mendelsohn, D. \& RABson, A. R. (1983). Characterization of a suppressor cell-activating factor (SCAF) released by adherent cells treated with $M$. tuberculosis. Journal of Immunology 130, 2266-2270.

WATSON, S. R. \& Collins, F. M. (1981). The specificity of suppressor T cells induced by chronic Mycobacterium avium infection in mice. Clinical and Experimental Immunology 43, 10-19.

Wolinsky, E. (1979). Nontuberculous mycobacteria and associated diseases. American Review of Respiratory Diseases 119, 107-159.

Woods, G. L. \& WASHINGToN, J. A., II (1987). Mycobacteria other than Mycobacterium tuberculosis: review of microbiologic and clinical aspects. Reviews of Infectious Diseases 9, 275-294.

Young, L. S., Inderlied, G. B., Berlin, O. G. \& GotTlieb, M. S. (1986). Mycobacterial infections in AIDS patients, with an emphasis on the Mycobacterium avium complex. Reviews of Infectious Diseases 8, 1024-1033. 